\title{
KAJIAN KRITIS PEMILIHAN KEPALA DAERAH CALON TUNGGAL PASCA PUTUSAN MAHKAMAH KONSTITUSI NOMOR 100/PUU-X111/2015
}

\author{
Erniyanti \\ Dosen Fakultas Hukum Universitas Batam \\ erniy725@gmail.com
}

\begin{abstract}
The issue of a single candidate election is rampant in the implementation of the 2015 elections. This is considered to threaten regional democracy in terms of democratic elections according to the 1945 Constitution. Therefore, this issue was resolved by the Constitutional Court through Decision of the Constitutional Court No. 100 / PUU-XIII / 2015 and stipulated by Law No. 10 of 2016. Referring to the two regulations, a single candidate can take part in the implementation of the elections with a referendum mechanism. The method used is a normative juridical method with a library approach. Therefore the legal materials used include primary legal materials, secondary legal materials and tertiary legal materials.
\end{abstract}

\begin{abstract}
Abstrak, Permasalahan pilkada calon tunggal marak terjadi pada pelaksanaan pilkada tahun 2015. Hal ini dinilai dapat mengancam demokrasi daerah dalam hal pemilihan secara demokratis menurut UUD 1945. Oleh karena itu, permasalahan ini diselesaikan oleh Mahkamah Konstitusi melalui Putusan MK No. 100/PUU-XIII/2015 dan ditetapkan dengan UU No. 10 Tahun 2016. Merujuk pada kedua regulasi tersebut, calon tunggal dapat mengikuti pelaksanaan pilkada dengan mekanisme referendum. Adapun metode yang digunakan adalah metode yuridis normatif dengan pendekatan kepustakaan. Oleh karena itu bahan hukum yang digunakan mencakup bahan hukum primer, bahan hukum sekunder dan bahan hukum tersier. Kata kunci: Pilkada, Calon Tunggal, Putusan Mahkamah Konstitusi
\end{abstract}

\section{Pendahuluan}

Merujuk pada ketentuan Pasal 1 Ayat (1) UUD Tahun 1945 menyebutkan bahwa: "negara Indonesia adalah negara kesatuan yang berbentuk republik". Hal ini kemudian dikuatkan dengan Pasal 18 Ayat (1) UUD Tahun 1945 yaitu: "Negara Kesatuan Republik Indonesia dibagi atas daerah-daerah provinsi dan daerah provinsi itudibagi atas kabupaten dan Kota, yang tiap-tiap provinsi, kabupaten, dan kota itu mempunyai pemerintahan daerah, yang diatur dengan undang-undang".

Melihat dari dua ketentuan di atas, dipahami adalah negara Indonesia merupakan negara berbentuk republik yang mana daerahnya merupakan daerah provinsi yang kedudukannya diatur dalam undang-undang. Jajaran pemerintah daerah tersebut secara lengkap terdiri dari Pemerintah daerah provinsi, daerah Kabupaten, dan Kota mengatur dan mengurus sendiri urusanpemerintahan menurut asas otonomi dan tugas pembantuan. Guna menjalankan fungsi otonomi dan tugas pembantuan tersebut dilaksanakan oleh satuan perangkat daerah yang bertanggungjawab kepada kepala daerah. 
Selanjutnya terkait pemilihan kepala daerah baik Gubernur, Bupati, dan Walikota masing-masing sebagai kepala pemerintah daerah provinsi,kabupaten dan kota dipilih secara demokratis. Pemaknaan dipilih secara demokratis dalam pemilihan kepala daerah tidak dibatasi dengan pelaksanaan pemilihan melalui pemilu. Hal ini merujuk pada kebiasaan pemilihan kepala daerah sebelum diberlakukannya UU No. 22 Tahun 1999 tentang Pemerintahan Daerah. Selanjutnya setelah ditetapkan UU No. 32 Tahun 2004 tentang Pemerintahan Daerah hingga disahkannya UU No. 23 Tahun 2014 tentang Pemerintahan Daerah dan UU No. 10 Tahun 2016 tentang perubahan kedua atas UU No. 1 Tahun 2015 tentang penetapan peraturan pemerintah pengganti UU No. 1 Tahun 2014 tentang Pemilihan Gubernur, Bupati, Dan Walikota menjadi Undang-Undang, maka pelaksanaa pemilihan kepala daerah dilaksanakan melalui mekanisme pemilu secara luber.

Pemerintah daerah bersama DPRD dan segenap komponen masyarakat diberi kebebasan menentukan apakah penyelenggaraan pilkada dilakukan secara langsung, perwakilan atau penetapan oleh DPRD. Sedangkan, untuk pemilihan gubernur bisa dilakukan dengan dipilih oleh anggota DPRD provinsi dan anggota DPRD kota/kabupaten dalam wilayah provinsi setempat.

Pemilihan kepala daerah (pilkada) diIndonesia merupakan amanah langsung darigerakan reformasi tahun 1998. Menimbangperlunya partisipasi yang kuat dari masyarakatuntuk ikut terlibat langsung dalam pemilihanpemimpinnya, maka pemilihan kepala daerahmenjadi momentum demokrasi yang palingpenting dalam kehidupan berbangsa danbernegara Indonesia. ${ }^{1}$

Berdasarkan ketentuan Pasal 42 UU No. 10 Tahun 2016 menyebutkan Pasangan Calon Gubernur dan Calon Wakil Gubernur, Calon Bupati dan Calon Wakil Bupatiserta pasangan Calon Walikota dan Calon WakilWalikota didaftarkan ke KPU Kabupaten/Kota olehPartai Politik, gabungan Partai Politik, atauperseorangan. ${ }^{2}$ Intisari keberlakuan Pasal 42 undang-undang tersebut menegaskan setiap calon kepala daerah wajib mendaftarkan diri ke KPU baik melalui partai politik, gabungan partai politik maupun perseorangan (independen).

Namun, perkembangan ketatanegaraan di daerah telah memunculkan sebuah fenomena baru yang merubah paradigma umum yang biasa dilakukan, khususnya dalam hal pelaksanaan pilada. Sebagaimana diketahui secara umumnya pilkada diikuti seminimalnya 2 (dua) pasang calon kepala daerah. Akan tetapi realitanya, terdapat beberapa daerah di Indonesia dimana calon kepala daerah yang telah mendaftar untuk ikut pelaksanaan pilkada hanya satu pasang calon. Bahkan telah dilakukannya perpanjangan jadwal pendaftaran oleh KPU.

Polemik tersebut ditindaklanjuti oleh MK dalam Putusan MK No. 100/PUUXIII/2015 dengan memperbolehkan pelaksanaan pilkada walau hanya diikuti oleh calon tunggal. MK menimbang perumusan norma UU Nomor 8 tahun 2015, yang mengharuskan adanya lebih dari satu pasangan calon tidak memberikan solusi, yang menyebabkan kekosongan hukum. Hal itu dapat berakibat pada tidak dapat

${ }^{1}$ Suyatno, Pemilihan Kepala Daerah (Pilkada) dan Tantangan Demokrasi Lokal di Indonesia, Jurnal Politik Indonesia: Indonesian Political Science Review, Vol. 1, No. 2, 2016, hlm. 213

${ }^{2}$ Lihat Pasal 42 Ayat (1) dan (2) UU No. 10 Tahun 2016 
diselenggarakannya pilkada. Jadi, syarat mengenai jumlah pasangan calon berpotensi mengancam kedaulatan dan hak rakyat untuk memilih. ${ }^{3}$

MK telah mengeluarkan keputusan Nomor 100/PUU-XIII/2015 yang menyatakan manifestasi kontestasi Pilkada lebih tepat dipadankan dengan pemungutan dengan cara "setuju atau "tidak setuju" dalam surat suara yang didesain sedemikian rupa sehingga memungkinkan rakyat untuk menentukan pilihan.Mekanisme ini akan menetepakan kepala daerah terpilih bila suara terbanyak adalah "setuju". Sebaliknya bila pilihan "tidak setuju" memperoleh suara terbanyak maka pemilihan ditunda sampai pilkada serentak berikutnya. ${ }^{4}$

Menindak lanjuti putusan MK tersebut, pemerintah telah merubah ketentuan UU No. 1 Tahun 2015 menjadi UU No. 10 Tahun 2016, khususnya pada Pasal 54C menegaskan bahwa: "Pemilihan 1 (satu) pasangan calon dilaksanakandengan menggunakan surat suara yang memuat 2(dua) kolom yang terdiri atas 1 (satu) kolom yangmemuat foto pasangan calon dan 1 (satu) kolomkosong yang tidak bergambar". ${ }^{5}$ Berdasarkan data yang diperoleh ada 3 daerah yang memiliki calon kepala daerah tunggal, antara lain Kabupaten Blitar, Kabupaten Tasikmalaya, dan Kabupaten Timor Tengah Utara di Nusa Tenggara Timur (NTT).

Atas dasar uraian yang dipaparkan di atas, maka rumusan masalah yang akan dikaji yaitu: 1) apakah pelaksanaan pilkada calon tunggal berdasarkan UU No. 10 Tahun 2016 telah sesuai dengan asas pelaksanaan pemilihan yang demokratis?. 2) Bagaimanakah realisasi pelaksanaan pilkada calon tunggal pasca putusan MK dikaitkan dengan asas demokrasi di daerah?

\section{Metode Kajian}

Adapun metode yang digunakan yaitu bersifat yuridis normatif dengan spesifikasi pendekatan peraturan perundang-undangan (statue approach). Oleh karena itu, data yang digunakan data sekunder yang mencakupi bahan hukum primer, bahan hukum sekunder, dan bahan hukum tersier. Setelah data dikumpulkan maka akan diklasifikasi untuk diuraikan dan dianalisa secara kualitatif.

\section{Pembahasan}

\section{Pelaksanaan Pilkada Calon Tunggal Berdasarkan UU No. 10 Tahun 2016 BerdasarkanAsas Pelaksanaan Pemilihan Yang Demokratis}

Pemilihan kepala daerah/pilkada sangatberkaitan erat dengan penyelenggeraankedaulatan rakyat di dalam suatu negara.Kedaulatan rakyat berarti rakyatlah yangmenentukan corak dan cara pemerintahan,dan rakyatlah yang menentukan

\footnotetext{
${ }^{3}$ https://nasional.kompas.com/read/2015/09/29/13474751/MK.Putuskan.Calon.Tunggal.Tetap.Men gikuti.Pilkada.Serentak

${ }^{4}$ https://www.cnnindonesia.com/nasional/20151001235658-32-82261/perludem-putusan-mk-soalcalon-tunggal-sudah-tepat

${ }^{5}$ Lihat Pasal 54C Ayat (2) UU No. 10 Tahun 2016
} 
tujuan apayang hendak dicapai. ${ }^{6}$ Pada hakikatnya salah satu jenis pemilihan umum. Menurut A.S.S Tambunan, "pemilihan umummerupakan sarana pelaksanaan asaskedaulatan rakyat pada hakikatnyamerupakan pengakuan dan perwujudandari pada hak-hak politik rakyat dansekaligus merupakan pendelegasian hakhaktersebut oleh rakyat kepada wakil-wakilnyauntuk menjalangkanpemerintahan. ${ }^{7}$

Pilkada yang demokratis konstitusional, damai dan bermartabat adalah pemilihan kepala daerah yang dalam proses pelaksanaannya transparan, akuntabel, kredibel, dan partisipatif, serta hasilnya dapat diterima oleh semua pihak, sehingga mampu menjamin hadirnya kemaslahatan bersama dalam masyarakat.

Merujuk pada ketentuan Pasal 18 Ayat (4) UUD Tahun 1945 menegaskan bahwa pemilihan kepala daerah diselenggarakan secara demokratis. Ada dua pendekatan terhadap demokrasi: pendekatan normatif dan pendekatan empirik. Pendekatan normatif, menekankan pada ide dasar dari demokrasi yaitu kedaulatan ada di tangan rakyat dan oleh karenanya pemerintahan diselenggarakan dari, oleh, dan untuk rakyat. Dalam perkembangannya, ide kedaulatan rakyat secara utuh sulit diterapkan selain beragam dan seringkali saling bertentangan, rakyat juga sulit dihimpun untuk penyelenggaraan pemerintahan sehari-hari. Oleh karena itulah muncul ide demokrasi yang terkonkretisasi dalam lembaga perwakilan, baik lembaga eksekutif, legislatif maupun yudikatif yang anggota-anggotanya dipilih dari partai politik atau perseorangan sebagai agregasi dari berbagai kepentingan rakyat. Sedangkan pendekatan empirik menekankan pada perwujudan demokrasi dalam kehidupan politik sebagai rangkaian prosedur yang mengatur rakyat untuk memilih, mendudukkan dan meminta pertanggungjawaban wakilnya di lembaga perwakilan. Wakil-wakil inilah yang kemudian membuat dan menjalankan keputusan publik. $^{8}$

Terkait dengan demokrasi dari segi etika politik, negara demokratis memiliki lima gugus ciri hakiki, yaitu: negara hukum; prinsip kontrol nyata masyarakat terhadap pemerintah; prinsip perwakilan melalui lembaga perwakilan yang dipilih melalui pemilu yang bebas; prinsip mayoritas; dan adanya prinsip jaminan terhadap hak-hak demokratis. ${ }^{9}$

Dalam kontestasi pilkada lansung, peran rakyat sangat menentukan bagi pasangan calon (Paslon) untuk terpilih sebagai kepala daerah. Kedekatan (proximity) dan keberpihakan pada agenda-aganda kerakyatan, menjadi modal bagi paslon untuk memenangkan konstestasi. Tujuan pilkada secara serentak salah satunya adalah untuk membuat relasi antara pemerintah pusat dengan daerah lebih dekat, kedekatan dapat berupa kesamaan program pembangunan, visi dan misi ataupun termasuk juga adalah

\footnotetext{
${ }^{6}$ Mohammad Syafei, Tinjauan Atas Putusan Mahkamah Konstitusi No : 100/PUUXIII/2015Tentang Calon Tunggal Dalam Pemilihan KepalaDaerah Dan Wakil Kepala Daerah, Jurnal Legal Opinion, Vol. 4 No. 5, 2016, hlm. 5

${ }^{7}$ ASS Tambunan, Pemilu Indonesia Dan SusunanDan Keududukan MPR,DPR dan DPRD, Binacipta,Bandung,hlm 381

8 Achmad Arifulloh, Pelaksanaan Pilkada Serentak Yang Demokratis, Damai Dan Bermartabat, Jurnal Pembaharuan Hukum, Vol. 2 No. 2 Tahun 2015, hlm. 303

${ }^{9}$ Ibid.
} 
cita- cita yang sama untuk memperkuat dan mengawal 4 pilar, Pancasila,UUD 1945, NKRI dan Bhinneka Tunggal Ika. ${ }^{10}$

Perhelatan pemilihan kepala daerah 2018 di 171 provinsi, kabupaten, dan kota diwarnai dengan munculnya satu pasangan calon saja. Ini terjadi di 13 daerah. Pilkada tetap akan diselenggarakan meski hanya ada satu pasangan calon dan berdasarkan undang-undang, maka calon tunggal akan disandingkan dengan kolom kosong. Adapun beberapa daerah yang dilansir munculnya calon tunggal diantaranya Kota Prabumulih, Sumsel, Kabupaten Lebak, Banten, Kabupaten Tangerang, Banten, Kota Tangerang, Banten, Kabupaten Pasuruan, Jatim, Kabupaten Karanganyar, Jateng, Kabupaten Enrekang, Sulsel, Kabupaten Minahasa Tenggara, Sulut, Kabupaten Tapin, Kalsel, Kabupaten Puncak, Papua, Kabuaten Mamasa, Sulbar, Kabupaten Jayawijaya, Papua Kabupaten Padang Lawas Utara, Sumut. ${ }^{11}$

Mekanisme tahapan pemilihan umumkepala daerah dengan calon tunggal terdapat dalam Pasal 14 dan 25 Peraturan KPU Nomor 14 Tahun 2015 Tentang Pemilihan Gubernur Dan Wakil Gubernur,Bupati Dan Wakil Bupati, Dan/Atau Walikota Dan Wakil Walikota Dengan Satu Pasangan Calon. Kendala yang terjadi terkait pemilihan umum kepala daerah dengan calon tunggal sebagai berikut: Peraturan perundangan kurang mampu mengakomodasi permasalahan pemilihan kepala daerah, lemahnya kualitas sumber daya penyelenggara pemilihan kepala daerah, kaderisasi partai politik kurang berjalan optimal, dan masih kurangnya pendidikan politik. Dengan terjadinya kekosongan hukum maka Mahkamah Konstitusi berhak mengeluarkan Putusan MK Nomor 100/PUU$\mathrm{XIII} / 2015$ dan dengan keluarnya putusan tersebut maka pemilihan umum kepala daerah dengan calon tunggal dapat terlaksana dengan keluarnya Peraturan KPU Nomor 14 Tahun 2015 Tentang Pemilihan Gubernur Dan Wakil Gubernur, Bupati Dan Wakil Bupati, Dan/Atau Walikota Dan Wakil Walikota Dengan Satu Pasangan Calon sebagai peraturan pelaksana. ${ }^{12}$

Putusan MK mengenai calon tunggal dansyarat calon perseorangan, menjadimomen penting bagi perbaikan tata kelola penyelenggaran pemilu kepaladaerah (pilkada) di Indonesia. MKmemutuskan untuk mempersilahkansetiap daerah yang hanya memiliki satu pasangan calon atau yang lebihdikenal dengan istilah calon tunggaluntuk tetap menyelenggarakanpilkada, dengan mekanismememberikan pilihan kepada pemilih, "setuju" atau "tidak setuju". Selainitu, MK memutuskan untukmengubah syarat dukungan calonperseorangan yang pada awalnyaberlandaskan pada persentase jumlah penududuk, menjadi persentasejumlah pemilih di daerah tersebut. ${ }^{13}$

Adapun bunyi amar Putusan MK No 100/PUU-XIII/2015, yaitu:

Mengabulkan Permohonan Pemohon untuk sebagian:

1) Menyatakan Pasal 49 ayat (9) UU No. 8 Tahun 2015 bertentangan dengan UUD 1945 dan tidak mempunyai kekuatan hukum mengikat (conditionally

\footnotetext{
${ }^{10}$ Moch. Mubarok Muharam, Pilkada Serentak dalam Pusaran Arus Perubahan (Harapan Sebuah Kesejahteraan), Letram (Lembaga Transformasi), Surabaya, 2015, hlm. 4

${ }^{11} \mathrm{https} / / / \mathrm{www} . \mathrm{bbc} . \mathrm{com} / \mathrm{indonesia/indonesia-42647891}$

${ }^{12}$ Tunki Rachman Sanusi, Implikasi Calon Tunggal Dalam Pemilihan Kepala Daerah Berdasarkan Putusan Mahkamah Konstitusi Nomor 100/PUU-XIII/2015 Dengan Sistem Pemilihan Umum Di Indonesia, Skripsi, Fakultas Hukum Universitas Pasundan, Bandung, 2016, hlm. i

${ }^{13}$ Mohammad Syafei, Op., Cit.., hlm. 6
} 
unconstitutional) sepanjang tidak dimaknai mencakup pengertian "menetapkan satu (1) pasangan calon gubernur dan calon wakil gubernur peserta pemilihan dalam hal setelah jangka waktu tiga (3) hari dimaksud terlampaui namun tetap hanya ada satu (1) pasangan calon gubernur dan wakil gubernur;

2) Menyatakan Pasal 50 ayat (9) UU No. 8 Tahun 2015 bertentangan dengan UUD 1945 dan tidak mempunyai kekuatan hukum mengikat (conditionally unconstitutional) sepanjang tidak dimaknai mencakup pengertian"menetapkan satu (1) pasangan calon bupati dan calon wakil bupati serta satu (1) pasangan calon walikota dan calon wakil walikota peserta pemilihan dalam hal setelah jangka waktu tiga (3) hari dimaksud terlampaui namun tetap hanya ada satu (1) pasangan calon bupati dan wakil bupati serta satu (1) pasangan calon walikota dan calon wakil walikota;

3) Menyatakan Pasal 51 ayat (2) UU No. 8 Tahun 2015 bertentangan dengan UUD 1945 dan tidak mempunyai kekuatan hukum mengikat (conditionally unconstitutional) sepanjang tidak dimaknai mencakup "menetapkan 1 (satu) pasangan calon gubernur dan calon wakil gubernur dalam hal hanya terdapat satu (1) pasangan calon gubernur dan calon wakil gubernur;

4) Menyatakan Pasal 52 ayat (2) UU No. 8 Tahun 2015 bertentangan dengan UUD 1945 dan tidak mempunyai kekuatan hukum mengikat (conditionally unconstitutional) sepanjang tidak dimaknai mencakup "menetapkan satu (1) pasangan calon bupati dan calon wakil bupati serta satu (1) pasangan calon walikota dan calon wakil walikota dalam hal hanya terdapat 1 (satu) pasangan calon bupati dan calon wakil bupati serta satu (1) pasangan calon walikota dan calon wakil walikota;

5) Menolak Permohonan untuk selain dan selebihnya

Merujuk pada diktum amar putusan di atas, maka terjadi perubahan terhadap undang-undang penyelenggaraan pilkada, khususnya prihal mekanisme pemilihan yang diatur dalam Pasal 54C UU No. 10 Tahun 2016 menyebutkan:

(1) Pemilihan 1 (satu) pasangan calon dilaksanakan dalam hal memenuhi kondisi:

a. setelah dilakukan penundaan dan sampai dengan berakhirnya masa perpanjangan pendaftaran, hanya terdapat 1 (satu) pasangan calon yang mendaftar dan berdasarkan hasil penelitian pasangan calon tersebut dinyatakan memenuhi syarat;

b. terdapat lebih dari 1 (satu) pasangan calon yang mendaftar dan berdasarkan hasil penelitian hanya terdapat 1 (satu) pasangan calon yang dinyatakan memenuhi syarat dan setelah dilakukan penundaan sampai dengan berakhirnya masa pembukaan kembali pendaftaran tidak terdapat pasangan calon yang mendaftar atau pasangan calon yang mendaftar berdasarkan hasil penelitian dinyatakan tidak memenuhi syarat yang mengakibatkan hanya terdapat 1 (satu) pasangan calon;

c. sejak penetapan pasangan calon sampai dengan saat dimulainya masa Kampanye terdapat pasangan calon yang berhalangan tetap, Partai Politik atau Gabungan Partai Politik tidak mengusulkan calon/pasangan calon pengganti atau calon/pasangan calon pengganti yang diusulkan dinyatakan tidak memenuhi syarat yang mengakibatkan hanya terdapat 1 (satu) pasangan calon; d. sejak dimulainya masa Kampanye sampai dengan hari pemungutan suara terdapat pasangan calon yang berhalangan tetap, Partai Politik atau Gabungan Partai Politik tidak mengusulkan calon/pasangan calon pengganti atau 
calon/pasangan calon pengganti yang diusulkan dinyatakan tidak memenuhi syarat yang mengakibatkan hanya terdapat 1 (satu) pasangan calon; atau e. terdapat pasangan calon yang dikenakan sanksi pembatalan sebagai peserta Pemilihan yang mengakibatkan hanya terdapat 1 (satu) pasangan calon.

(2) Pemilihan 1 (satu) pasangan calon dilaksanakan dengan menggunakan surat suara yang memuat 2 (dua) kolom yang terdiri atas 1 (satu) kolom yang memuat foto pasangan calon dan 1 (satu) kolom kosong yang tidak bergambar.

Pelaksanaan pemilihan kepala daerah dengan calon tunggal terkait Putusan Mahkamah Konstitusi Nomor: 100/PUU-XIII/2015 tentang Pasangan Calon Tunggal Dalam Pemilihan Kepala Daerah merupakan dasar hukum yang berkekuatan hukum tetap agar tidak terjadinya penundaan pemilihan kepala daerah, guna menjaga hak konstitusional warga negara yang telah diatur dalam Undang-Undang Dasar Negara Republik Indonesia Tahun 1945. Sehingga disatu sisi Putusan MK tersebut dinilai telah menyelamatkan prinsip demokrasi di daerah dengan tetap mengikutsertakan calon tunggal dalam pelaksanaan Pilkada tersebut.

\section{Realisasi Pelaksanaan Pilkada Calon Tunggal Pasca Putusan MK Dikaitkan Dengan Asas Demokrasi Di Daerah}

Putusan Mahkamah Konstitusi Nomor 100/PUU-XIII/2015 tanggal 29 September 2015 yang substansinya membalikkan situasi politik secara nasional dengan mengijinkan pelaksanaan Pemilukada Serentak tahun 2015 dengan satu pasangan calon membuka babak baru dalam kontestasi politik di Indonesia. Paradigma yang terbangun sebelumnya bahwa pemilukada sebagai perwujudan demokrasi dan sarana aspirasi suara rakyat dalam proses transisi kepemimpinan daerah harus dilaksanakan dengan memilih diantara beberapa pasangan calon menjadi berubah dengan dapat dilaksanakan suatu pemilihan hanya pada satu pasangan calon. ${ }^{14}$

Pada aspek teknis, pemilukada dengan pasangan calon tunggal yang diputuskan MK juga tidak luput dari problematika yang berpotensi muncul ke permukaan paska pemilukada. Dengan teknis yang menyerupai referendum, maka hasil yang didapat dari pemilukada bisa menjadi semacam legitimasi untuk menggugurkan hak dipilih pada pasangan calon yang gagal memperoleh kemenangan dalam pemungutan suara. Mungkin akan moderat persepsi yang terbangun jika secara teknis menggunakan metode melawan kursi kosong jika dibandingkan semacam referendum. Belum lagi jika terdapat sengketa hasil pemilukada, maka penentuan pihak-pihak manakah yang dianggap berhak mengajukan sengketa akan menjadi polemik di kemudian hari.

Proses persiapan pemilukada serentak tahun 2015 melahirkan berbagai polemik politik yang berkepanjangan. Pada titik tertentu bahkan sanggup membangun suatu pola dinamika baru dalam proses berpolitik di Indonesia. Melalui proses yang panjang dengan gugat-menggugat di Mahkamah Konstitusi pada akhirnya dapat tercipta suatu konsep dan metode baru dalam proses berpolitik di Indonesia.

\footnotetext{
${ }^{14}$ http://ppid.bawaslu.go.id/sites/default/files/informasi_publik/Riset\%20Calon\%20Tunggal\%20Pil kada\%20Tahun\%202015.pdf
} 
Dinamika politik antara pembentukan UU No. 22 Tahun 2014 hingga UU No. 8 Tahun 2015 tidak dapat dipisahkan dari lahirnya Putusan MK No. 100/PUU-XIII/2015 mengenai adanya calon tunggal. MK membolehkan keikutsertaan calon tunggal dalam mengikuti pilkada untuk mengantisipasi kekosongan hukum. Implikasi yang terjadi yaitu akan memunculkannya deadlock di pertengahan jalan karena banyaknya daerah yang terancam batal melakukan pilkada akibat hanya satu pasangan calon. Guna menjawab permasalahan yang terjadi dan tidak adanya status vacum dalam pemerintahan maka pelaksanaan Putusan MK No. 100/PUU-XIII/2015 wajib dilaksanakan sesuai dengan prinsip demokrasi daerah. ${ }^{15}$

Sebagaimana contoh, terselenggaranya pilkada serentak dengan satu pasangan calon yang terjadi di Kabupaten Blitar bukan berarti tanpa cela. Selain beberapa daerah belum mengetahui secara benar tata cara pemilihan pada pemilihan referendum, pelaksanaan pilkada pada tanggal 9 Desember 2015 juga disinyalir kurang partisipasi masyarakat. KPUD Kabupaten Bllitar menyatakan bahwa jika dibandingkan dengan pemilu legisltaif, proses pelaksanaan pilkada serentak tahun 2015 tergolong rendah.

Alasan terbesar mengapa Kabupaten Blitar hanya mampu menghasilkan satu pasang calon kepala daerah adalah karena keengganan partai politik untuk mengusung calonnya. Terkait dengan proses pelaksanaan pilkada serentak yang hanya diikuti oleh satu paslon, masih terdapat beberapa permasalahan seperti kurangnya sosialisasi yang dilakukan oleh KPUD Kabupaten Blitar tentang tata cara proses pemngutan suara di TPS dengan surat suara "setuju" dan "tidak-setuju." Selain beberapa daerah belum mengetahui secara benar tata cara pemilihan pada pemilihan referendum, partisipasi masyarakat dalam pelaksanaan pilkada pada tanggal 9 Desember 2015 juga masih rendah. Karena faktor cuaca yakni pada saat pelaksanaan pilkada di Kabupaten Blitar diguyur hujan, banyak warga yang lebih memilih pergi ke sawah daripada pergi ke Tempat Pemungutan Suara (TPS). Faktor lain seperti tidak adanya pemilih yang berada di Kabupaten Blitar juga mendukung minimnya tingkat partisipasi masyarakat. Geliat pilkada serentak juga minim partisipasi dikarenakan beberapa warga sengaja tidak memilih dengan alasan calon fgur yang tidak cocok dengan hati nuraninya. Beberapa warga merasa bahwa tidak ada kompetisi dalam pilkada. Olehkarenanya, tingkat partisipasi partai politik ataupun calon independen untuk ikut serta dalam proses pilkada juga mempengaruhi tingkat partisipasi masyarakat untuk memilih dan memberikan hak pilihnya.

Calon tunggal dalam pilkada serentak yang terjadi di beberapa daerah di Indonesia merupakan salah satu bentuk demokrasi empirik. Keadaan munculnya "calon tunggal" adalah keadaan yang secara normatif tidak terbayangkan. Hal ini berarti bahwa, demokrasi dalam implementasi terus berkembang dan dipengaruhi oleh sistem politik yang terjadi di daerah tersebut. Pada dasarnya, pelaksanaan atau implementasi suatu teori tidak bisa dilakukan sama persis dengan apa yang dikehendaki oleh teori atau konsep tersebut. Contohnya, Indonesia menganut sistem presidensiil dengan multipartai. Padahal secara konsep, pemerintahaan presidensiil dengan multi partai dapat menganggu kestabilan Presiden karena kuatnya gesekan antara eksekutif dan legislatif. Sama halnya

${ }^{15}$ Nur Rukiyanto, Dinamika Pemilihan Kepala Daerah Calon Tunggal Pasca Putusan Mahkamah Konstitusi No. 100/PUU-XIII/2015 (Studi Kasus di Kabupaten Blitar Tahun 2015), Fakultas Syariah dan Hukum Universitas Islam Negeri Sunan Kalijaga, Yogyakarta, 2017, hlm. ii 
dengan pilkada dengan calon tunggal, secara konsep pilkada dengan calon tunggal tidak dapat dikatakan tidak demokratis. Esensi utama demokrasi adalah keterlibatan nyata masyarakat dalam penyelenggaraan pemerintahan. Dalam hal ini, rakyat adalah penentu kekuasaan dalam penyelenggaraan pemerintahan yang diberikan oleh wakil-wakilnya melalui proses pemilihan sebagai kontrak sosial. Di samping itu, terdapat aspek kearifan lokal yang tidak dapat ditinggalkan begitu saja, dalam arti bahwa kearifan lokal harus menjadi bahan pertimbangan dalam pelaksanaan demokrasi. Munculnya calon tunggal dalam pilkada adalah suatu pelajaran bahwa demokrasi yang berjalan dalam tataran praktik akan selalu berkembang secara dinamis, dan hukum harus mampu mengikuti perkembangan masyarakat tersebut. ${ }^{16}$

Fenomena calon tunggal, khususnya yang terjadi di Kabupaten Blitar, jika dipandang secara teoritis bukanlah merupakan hal yang dapat dikatakan tidak demokratis. Partisipasi merupakan poin yang utama pula dalam pelaksanaan demokrasi politik. Meskipun hanya ada satu pasangan calon dalam pilkada, proses pemungutan suara tetap merupakan hal yang harus dikerjakan karena hak pilih masyarakat merupakan kedaulatan rakyat yang keberadaannya dijamin oleh konstitusi.

\section{Penutup}

Putusan Mahkamah Konstitusi Nomor 100/PUU-XIII/2015 telah membawa perubahan paradigma pelaksanaan demokrasi daerah. Dimana MK telah membatalkan ketentuan UU No. 1 Tahun 2015 dengan membolehkan calon kepala daerah tunggal untuk maju dalam pelaksanaan pilkada. Hal ini ditindaklanjuti dengan diberlakukannya UU No. 10 Tahun 2016. Mekanisme pemilihan dilakukan dengan memilih setuju dan tidak setuju pada kertas suara. Merujuk pada asas demokrasi daerah terkait pemilihan kepala daerah menurut UUD 1945, putusan MK dinilai telah menyelamatkan demokrasi daerah dari kekosongan kekuasaan tingkat daerah.

Pada realisasinya pelaksanaan pilkada dengan calon tunggal dimanifestasikan dengan model referendum yaitu setuju dan tidak setuju memilih calon tunggal tersebut. Maraknya calon kepala daerah tunggal di beberapa daerah mengindikasikan partai politik masih kurang merealisasikan tujuan politiknya dalam bentuk pendidikan politik sehingga masyarakat menjadi apatis terhadap pelaksanaan demokrasi daerah.

\section{Daftar Pustaka}

\section{Buku:}

Achmad Arifulloh, Pelaksanaan Pilkada Serentak Yang Demokratis, Damai Dan Bermartabat, Jurnal Pembaharuan Hukum, Vol. 2 No. 2 Tahun 2015

Mohammad Syafei, Tinjauan Atas Putusan Mahkamah Konstitusi No : 100/PUUXIII/2015Tentang Calon Tunggal Dalam Pemilihan KepalaDaerah Dan Wakil Kepala Daerah, Jurnal Legal Opinion, Vol. 4 No. 5, 2016

${ }^{16}$ Wafia Silvi Dhesinta, Calon Tunggal Dalam Pemilihan Umum Kepala Daerah Dan Konsep Demokrasi Analisa Terhadap Pemilihan Kepala Daerah Kabupaten Blitar 2015, JURNAL JENTERA Volume 1 No.1, Juni 2017, hlm. 39 
Mubarok Muharam Moch., Pilkada Serentak dalam Pusaran Arus Perubahan (Harapan Sebuah Kesejahteraan), Letram (Lembaga Transformasi), Surabaya, 2015

Nur Rukiyanto, Dinamika Pemilihan Kepala Daerah Calon Tunggal Pasca Putusan Mahkamah Konstitusi No. 100/PUU-XIII/2015 (Studi Kasus di Kabupaten Blitar Tahun 2015), Fakultas Syariah dan Hukum Universitas Islam Negeri Sunan Kalijaga, Yogyakarta, 2017

Suyatno, Pemilihan Kepala Daerah (Pilkada) dan Tantangan Demokrasi Lokal di Indonesia, Jurnal Politik Indonesia: Indonesian Political Science Review, Vol. 1, No. 2, 2016

Tambunan ASS., Pemilu Indonesia Dan SusunanDan Keududukan MPR,DPR dan $D P R D$, Binacipta,Bandung.

Tunki Rachman Sanusi, Implikasi Calon Tunggal Dalam Pemilihan Kepala Daerah Berdasarkan Putusan Mahkamah Konstitusi Nomor 100/PUU-XIII/2015 Dengan Sistem Pemilihan Umum Di Indonesia, Skripsi, Fakultas Hukum Universitas Pasundan, Bandung, 2016

Wafia Silvi Dhesinta, Calon Tunggal Dalam Pemilihan Umum Kepala Daerah Dan Konsep Demokrasi Analisa Terhadap Pemilihan Kepala Daerah Kabupaten Blitar 2015, JURNAL JENTERA Volume 1 No.1, Juni 2017

\section{Internet:}

https://nasional.kompas.com/read/2015/09/29/13474751/MK.Putuskan.Calon.Tunggal.Te tap.Mengikuti.Pilkada.Serentak

https://www.bbc.com/indonesia/indonesia-42647891

http://ppid.bawaslu.go.id/sites/default/files/informasi_publik/Riset\%20Calon\%20Tunggal \%20Pilkada\%20Tahun\%202015.pdf

https://www.cnnindonesia.com/nasional/20151001235658-32-82261/perludem-putusanmk-soal-calon-tunggal-sudah-tepat 